\title{
Patent suit on Alzheimer's mouse rejected...
}

\section{Rex Dalton, San Diego}

Neuroscientists worldwide can continue to enjoy access to an important transgenic mouse used for research into Alzheimer's disease, following the rejection of a patentinfringement claim against the institution that distributes the mice.

Elan Pharmaceuticals, Inc., based in Ireland, filed a suit against the Minnesotabased, non-profit Mayo Foundation for Medical Education and Research last year, alleging that two of its US patents for transgenic mice were being infringed by the foundation's strain of transgenic mice (see Nature 404, 319-320; 2000). If successful, the move could have blocked the Mayo Foundation's distribution of the mice.

But on 15 June, Judge William Alsup of the US District Court in San Franciso dismissed Elan's lawsuit. He ruled that the company's two patents were invalid, as they involved technology already included in an earlier patent that the Mayo Foundation was licensed to use.

"This is really fantastic news," says Steve Younkin, a neuroscientist at Mayo's facility in Jacksonville, Florida, where its Alzheimer's research is concentrated.

Elan intends to appeal against the decision. "We are confident the patents are valid and the court will reverse the decision," says Libby Murphy, Elan's executive vice-president for intellectual property and legal affairs. An Elan spokesman adds, "It is unfortunate we have to defend our intellectual property against the Mayo Foundation, as we have worked closely with them in the past and hope to do so in the future."

The Mayo Foundation's transgenic mice were developed and distributed using technologies licensed from the University of Minnesota and a small Kansas company, the Alzheimer's Institute of America.

Judge Alsup ruled that the Alzheimer's Institute's technology, patented by neuroscientist Michael Mullan of the University of South Florida (see right), preceded Elan's patent disclosures. "The Mullan patent application disclosed the same recipe for making transgenic mice as was later disclosed in the [Elan] patents," Alsup wrote in his eight-page ruling.

Karen Boyd, the Mayo Foundation's attorney with the law firm of Fish \& Richardson, says the court ruling "gives researchers at the Mayo Foundation, other academic institutions and biotechnology companies the opportunity to continue research".

The transgenic mice of both organizations are different, but they both involve engineering the mice to have a human genetic mutation that is linked to a build-up of amyloid protein leading to neurodegeneration in the brain.

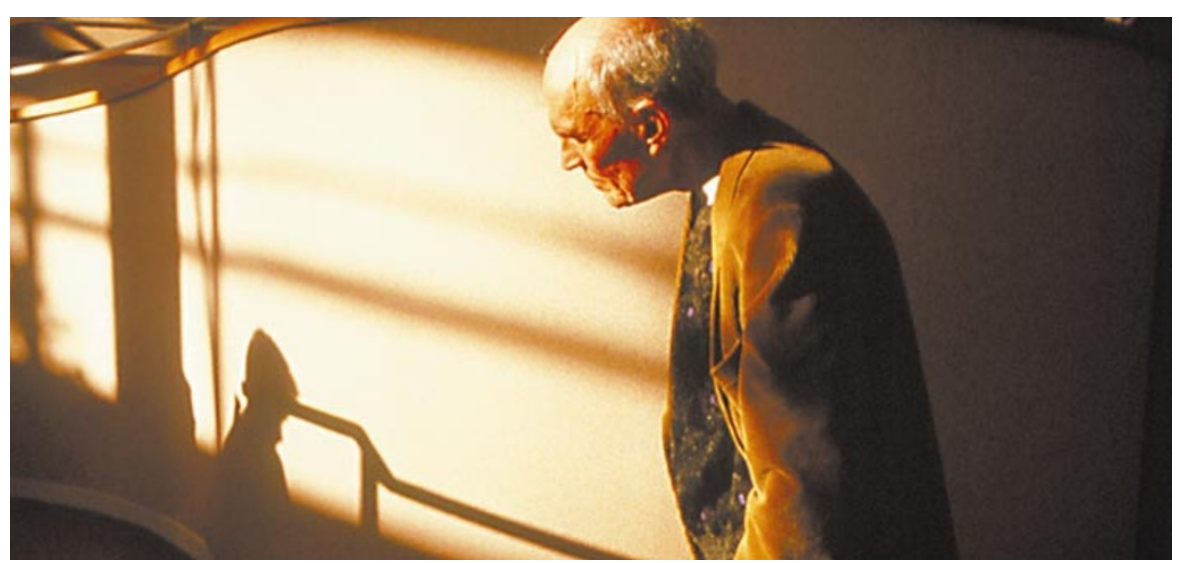

Threat lifted: Alzheimer's patients stand to benefit from research with the Mayo Foundation's mice.

The Mayo Foundation has been distributing its mice to academic institutions at nominal costs, although it has been charging some pharmaceutical companies as much as $\$ 850,000$ for a breeding group.

Elan is known for exerting tight control over the distribution of its products to academic researchers and other drug companies.
Two disputed patents were acquired when Elan purchased Athena Neurosciences, Inc. in 1998. If the court ruling stands after Elan's appeal, the two patents would be permanently invalidated, and the US Patent and Trademark Office would withdraw them. A decision by an appeals court in Washington usually takes a year.

\section{......... controversy over rights lingers on}

A patent at the centre of a heated court battle over tools used for research into Alzheimer's disease (see above) itself emerged from a controversial arrangement between an expatriate British scientist and a public university in Florida. In addition, a Swedish research team argues that it should have shared in the rights.

The patent covers the genetic sequence of a human mutation that causes Alzheimer's disease and its use in transgenic mice (Nature Genet. 1, 345-347; 1992). It was invented by Michael Mullan, a neuroscientist who trained at Imperial College in London.

Mullan says he received the rights to the discovery under a deal with the University of South Florida in Tampa.

Mullan left England in 1992 and moved to the university having, he says, become disheartened with how he was treated when Imperial College sought to capitalize on his scientific discoveries.

Mullan says his terms of employment at South Florida allowed him to own the patents on any scientific discoveries he made within about six months of his arrival in Florida.

During this time Mullan and his colleagues sequenced the gene in question. Mullan sold the patent rights to the Alzheimer's Institute of America, a company set up by Kansas venture capitalist Ron Sexton, who had been funding Mullan's work. The Mayo Foundation later licensed the technology from Sexton's firm. Kenneth Preston, the University of South Florida's director of patents and licensing, acknowledges that initially "there was an agreement not to apply rules and procedures regarding intellectual property" to Mullan. He also accepts that, as a result, a discovery that would normally have been owned by the university ended up in private hands.

Mullan, who now directs the university's Roskamp Institute, says that he did everything "above board" and "in full view of everyone". He says that the university's officials "felt sympathetic" to him for having been badly treated by Imperial College. The college declines to comment on the issue.
In 1991, Imperial College sold the rights to the first Alzheimer's mutation that Mullan helped to discover (see Nature 353, 844-846; 1991) to Athena Neurosciences, Inc., which was later bought by Elan, the company at the heart of last week's court hearing.

Another twist is the fact that the DNA used by Mullan to sequence the mutation at South Florida was provided by a Swedish research team headed by Bengt Winblad, chief of clinical neuroscience at the Karolinska Institute in Stockholm.

In publishing the findings, Mullan shared co-authorship with the Swedes in the 1992 Nature Genetics article. But he listed himself as sole inventor on the US patent, which was granted in 1995.

Lars Lannfelt, a neurogenetics professor on Winblad's team who unsuccessfully fought for recognition on the patent, claims that he and his colleagues should not have been omitted. Mullan denies this, arguing that the Swedish researchers "didn't have a position" as inventors, because they only provided DNA, and made no intellectual contribution. R. D. 